\title{
Participation of Local Community in Supporting East Nusa Tenggara Priority Programs
}

\author{
(Case Study in Fatumnasi Tourism Village, Timor Tengah Selatan)
}

\author{
Syul Rosli Sanam*, Yudha Eka Nugraha, Laurensius Sandro Rero \\ Hospitality Department \\ Politeknik Negeri Kupang \\ Kupang, Indonesia \\ *unnyesanam@gmail.com, yudhaekanugraha@gmail.com, laurensandrorero@gmail.com
}

\begin{abstract}
This research was conducted in Fatumnasi Village, which has been designated as a priority rural tourism development program in NTT. In the context of developing rural tourism strengthening active participation of local communities is important towards prosperous communities. This research is focused on what form and effort used to increase the participation of local communities in supporting priority development programs in NTT. The approach uses descriptive qualitative, which used to analyse, describe, and obtain objective description of main problem of this study. Data collected in this study are observation, FGD, literature study and documentation. The results of this study shows that community participation included the formation of Pokdarwis, provision of facilities and infrastructure, packaging of local products, involvement in training and guidance on tourism. Community participation efforts that need to be done are, involved in training and coaching to be able to improve tourism human resources, cooperation between community groups in packaging local products, and cooperation between stakeholders in promoting local products.
\end{abstract}

Keywords-tourism destination, community partisipation, community based tourism

\section{INTRODUCTION}

The Indonesian government believes that tourism is a sector that can be developed to support the progress of its development. Tourism development in Indonesia is based on Law no. 10 of 2009 concerning tourism has the following objectives: (a) increasing economic growth, (b) increasing people's welfare, (c) eliminating poverty, (d) overcoming unemployment, (e) preserving nature, social and culture, (f) promote culture, $(\mathrm{g})$ raise the image of the nation, $(\mathrm{h})$ foster a sense of love for the country, (i) strengthen national identity and unity, (j) strengthen friendship between nations [1].

In the 1993 GBHN, it is stated: "Tourism development is directed at increasing tourism to become a mainstay sector capable of promoting economic activity, including other related sectors, so that employment, community income, regional income, state income, and foreign exchange revenue increase through development and utilization of the potential of national tourism". In this regard, more aggressive, more serious, targeted and sustainable efforts are needed in equitable tourism development.

Realizing this, the Province of NTT, which has been designated as one of the leading tourist destinations since 2007, has now started to play an active role in improving its tourism sector. This is further strengthened by one of the NTT Regional Development missions by the elected NTT Governors for the 2018-2023 period, which aims to "increase tourism development in the context of empowering the people's economy. Building NTT as one of the gates and centres for the development of National tourism (New Tourism Territory)". The NTT Provincial Government has begun to realize this mission by establishing 7 (seven) regions as Priority Destinations, namely, Fatumnasi South Central Timor Regency (TTS), Lamalera Lembata Regency, 1000 Mouth Rote Ndao Regency, Liman Beach, Kupang Regency, Koanara Village, Ende Regency, Wolwal Regency Alor, and Praimadita, East Sumba Regency, based on the availability of ready-to-pack tourism products.

Fatumnasi which is included in this category is located in Fatumnasi Village, Fatumnasi District, TTS Regency which is at an altitude of 1150 MDPL. Fatumnasi Village, which is known as a tourist village, has natural beauty and cultural uniqueness that is very potential and worthy of being developed. This area is not only famous for its tourism potential but also as an agricultural producer in the form of vegetables, tubers and fruits which have the potential to be used as agro-tourism capital.

In developing village-based tourism attractions, it must be oriented towards strengthening the involvement and participation of local communities. Related to the development of this tourism village, of course it cannot be separated from the involvement and participation of local communities. Apart from being a destination owner, he also plays a role as the main actor who must be prepared to receive tourist arrivals. The enthusiasm of the people of Fatumnasi Village can give a 
positive reaction to the NTT Provincial government as a facilitator who can spur local communities through the formation of a Tourism Awareness Group (Pokdarwis) and collaborating with tourism academics in providing training on how to process and package food into local culinary delights, providing homestay, hospitality and tour guiding.

Glancing from the weakness of Human Resources (HR) of the local community, it needs to be equipped so that they are not rigid in welcoming tourists and can play an active role in building this tourist village. Community participation is expected not only to rely on tourist servants but to be able to provide all the needs and desires of tourists in a prime manner. The main objective is to provide additional alternatives in improving the standard of living of local communities and providing and absorbing labour. For this reason, the community needs to be actively involved from the start of planning, development, to management.

\section{LITERATURE REVIEW}

\section{A. Tourism Destinations}

The concept of tourism destinations is one of the most important and complex in the discussion of tourism. Tourism Destinations or Tourist Destination Areas are geographic areas that are located in one or more administrative areas in which there are tourist attractions, public facilities, tourism facilities, accessibility, and related communities. and complement the realization of tourism [1]. Tourism destinations as a tourist travel market area and refers to the travel destination zone, namely a geographical area that includes regional development and society in order to satisfy tourist travel destinations. Therefore, tourism destinations can be described at different scales ranging from the village level to the region, city or resort, special sites and even only in the form of special attractions visited by tourists [2].

In principle, a tourist attraction must meet three conditions, namely: (1) Something to see, in that place there must be different tourist objects and attractions from those of other regions. In other words, the area must have a special attraction and cultural attractions that can be used as "entertainment" for tourists. What to see includes natural scenery, activities, arts and tourist attractions. (2) Something to do, in a place other than what can be seen and witnessed, recreational facilities must be provided that can make tourists feel at home for a long time in that place. (3) Something to buy / souvenir. Tourist destinations must have facilities for shopping, especially souvenirs and folk handicrafts as souvenirs to take home to their place of origin [3].

The development of tourism destinations consists of the following main components: (1) the object of 'tourist attraction, which includes uniqueness and attractiveness based on nature, culture, and artificial; (2) Accessibility, which includes the ease of transportation facilities and systems; (3) Amenities which include supporting and supporting tourism facilities; (4) Public facilities (Ancillary Service) that support tourism activities; (5)
Institutions that have the authority, responsibility and role in supporting the implementation of tourism activities [4]

\section{B. Community Participation}

Community participation is the involvement and or participation of the community consciously and voluntarily in the development process which includes the decision-making stage, the activity implementation stage, the development monitoring and evaluation stage, and the development result utilization stage. Community participation in development activities is a manifestation of community awareness and concern and responsibility for the importance of development aimed at improving their quality of life [5].

The scope of community participation in development, namely: (1) Participation in decision making; (2) Participation in the implementation of activities; (3) Participation in development monitoring and evaluation; and (4) Participation in the utilization of development results. Community participation in development is very much determined by three main elements, namely: (1) There is an opportunity given to the community to participate; (2) Community willingness to participate; and (3) The community's ability to participate [5].

\section{Community Based Tourism}

Seeing the development of tourism that focuses on the concept of community-based tourism, it is now starting to change the mind-set of local people about its important role in empowering existing tourism resources. On this occasion also, the community is empowered in the management of a tourism destination which is calculated to provide benefits for improving the welfare of the community itself. Community empowerment as a process that not only develops the economic potential of people who are helpless, but also seeks to improve their dignity, self-confidence and self-esteem as well as the maintenance of local cultural values. Community-based tourism is interpreted as an effort to strengthen the power or empowerment of powerless groups of people, usually those who are classified as marginalized communities [4]

In principle, community-based tourism is one of the important and critical ideas in the development of conventional tourism development theory which has often received a lot of criticism for neglecting rights and marginalizing local communities from tourism activities in a destination. In connection with tourism development, there are several parties that have a role and are directly involved, namely the government, private actors and local communities. These three (3) pillars have an important role in tourism development which must work together to achieve the goals and objectives of its development. Apart from the government and private actors, the role of local communities has an equally important position as one of the stakeholders [4].

Community Based Tourism (CBT) as tourism that takes into account environmental, social and cultural aspects of sustainability. CBT is a tool for realizing sustainable tourism development. There are 5 dimensions in the main aspects of 
developing CBT, namely: (1) The economic dimension, with indicators in the form of funds for community development, the creation of jobs in the tourism sector and the emergence of local community income from the tourism sector; (2) Social dimension, with indicators of increasing quality of life; increased community pride; equitable distribution of roles between men, women, young and old generations; building strengthening community organizations; (3) The cultural dimension, with indicators in the form of encouraging people to respect different cultures, fostering cultural exchange, development culture that is closely attached to local culture; (4) Environmental dimension, with indicators of studying carrying capacity areas, regulating waste disposal, increasing awareness of the need for conservation; (5) The political dimension, with indicators of increasing the participation of the local population, increasing the satisfaction of the wider community, guaranteeing rights in natural resource management [6]

From this statement, it can be concluded that communitybased tourism is an activity that includes all levels of society in the planning, development and management of tourism, so as to realize sustainable tourism development, which can provide positive benefits to the economy towards improving the welfare of local communities, advancing culture, as well as conserving nature, the environment and other resources.

\section{METHOD}

The approach to analysing this problem is to use qualitative descriptive analysis, namely to analyse, describe, and obtain a clear and objective picture of the problem under study. Meanwhile, data collection consists of direct observation, interviews, Focus Group Discussion (FGD), literature study and documentation.

\section{A. Location and Research Duration}

This research was conducted in Fatumnasi Village, Fatumnasi District, Timor Tengah Selatan Regency. The research was conducted from July to November 2020, until the saturation point was found in the data in the field.

\section{B. Research Subject}

The research subject is a person or resource person who can provide actual information regarding the state and whereabouts of the object under study, so that what can be obtained in this research is precise and accurate. The interviewees related to this research were the Head of Fatumnasi Village, community leaders, and the Head of Pokdarwis. Furthermore, the subjects in the data collection method through FGDs are local communities and Pokdarwis members, who are expected to obtain a lot of information in accordance with a high level of data validity.

\section{Research Instruments}

In order to collect and obtain valid data, an instrument is needed. In qualitative research, findings or data can be declared valid, if there is no difference between what the researcher reports and the conditions that occur in the object under study. In this study, the researcher acts as a data collector and as an active instrument in an effort to collect data in the field. Meanwhile, other data collection instruments besides humans are various forms of assistive devices, other documents that can be used to support the validity of research results which function as supporting instruments. Therefore, the presence of researchers directly in the field as a measure of success so that direct involvement of researchers is absolutely necessary. The instruments used in this study were interview guides, cameras, recording devices and writing instruments [7].

\section{Data Analysis Techniques}

Data analysis technique is the process of categorizing data sequences, organizing them into a pattern, category and basic description unit, differentiating them from interpretation, namely giving significant meaning to the analysis, explaining the pattern of description and looking for relationships between the dimensions of description [7].

In general, the data analysis technique used in this research is descriptive qualitative analysis, namely by describing, describing, and explaining systematically, actual and accurately based on direct observation, interviews, Focus Group Discussion (FGD), documentation and literature study. From the data obtained, then it is reduced to then presented, conclusions and verification are drawn so as to obtain clear and objective results.

\section{RESULTS AND DISCUSSION}

Fatumnasi Village is administratively included in the Fatumnasi District, South Central Timor Regency, East Nusa Tenggara Province. The location is at the foot of Mount Mutis which is the highest mountain on the island of Timor (2247 MDPL). The population of Fatumnasi Village is 1,520 people with a total of 552 families. The livelihoods of the population are farming (various vegetables, upland rice, corn, tubers, coffee) and livestock (goats, cows, horses, buffalo), honey producers and handicraft producers in the form of quality weaving. The level of education of the people of Fatumnasi Village is still low, because the majority are only elementary school to high school graduates. With regard to tourism activities, managed by the entire community, facilitated by the NTT Provincial Tourism Office.

In the development of community-based tourism, emphasizing that the community does not only act as an audience but as a major player in the development itself. The participation of local communities cannot be ignored. Local people are the first to know about the condition of their area than people who come from outside the region. Thus, local community participation is needed both in planning, implementation, development until the end, namely job evaluation. The hope in the future is that there is nothing else to create an attitude of belonging to the local community itself, so that awareness and responsibility arise to participate in developing tourist attractions 


\section{A. Forms of Local Community Participation}

Based on the results of research in Fatumnasi Tourism Village, it shows that there are several forms of local community participation that have been realized in supporting the development of current tourist destinations, which can be described as follows:

1) Participation in forming Pokdarwis: In developing the Tourism Village, Fatumnasi has involved local communities who are members of the Tourism Awareness Group (Pokdarwis), which is that all Pokdarwis members come from the local community themselves. Indeed, not all local communities are members of Pokdarwis, but these members already represent the community as a whole. The realization of the active involvement of the local community has been carried out well, starting from the planning stage until now community participation activities are still being carried out well although they are still very limited. However, there is no transparency between pokdarwis in the community regarding a clear organizational structure, main duties and functions of each member.

2) Participation in the form of facilities and infrastructure: The people of Fatumnasi Village participate in tourism development both in ideas, energy and assets. This means that in supporting the implementation of tourism activities, the community often expresses their related opinions through internal meetings and socialization with academics and practitioners who have been supporting the development of this tourist destination. Besides that, the community cooperates with each other in fixing facilities and infrastructure such as drinking water and road repairs, then the community also participates in providing lodging in the form of a homestay, namely Lopo Mutis which is owned by Mr. Matheos Anin. Through a government program, currently it has provided lodging in the form of cottages whose aim is to empower local communities, by employing local people who can later increase economic growth in this area.

3) Participation in packaging local product: Realizing that it is not only the potential for natural beauty and the uniqueness of Fatumnasi's culture that is known to the wider community. Now the community has taken the initiative to package their local products to be marketed, such as woven cloth crafts, processed food products in the form of taro chips, sweet potato bananas, corn, advocat oil, and processed forest products in the form of honey which are now packaged and marketed. In addition to packaging marketed products, local people are also involved as local guides who are ready to take tourists around this tourist village.

4) Participation in tourism training and development: Realizing the shortcomings and limitations in education, local people now have very high enthusiasm and curiosity to involve themselves in training and coaching activities on tourism villages, both those held in Fatumnasi Village and in organizing activities that are carried out outside. It can be said that Fatumnasi Village received full attention from visiting government agencies and academics to provide socialization to increase awareness and readiness of local communities to host tourists. The NTT Tourism and Culture Office collaborates with Kupang State Polytechnic academics in providing knowledge to local communities through socialization, training and coaching and implementation of community service which has been held several times in Fatumnasi.

Based on the results of the Focus Group Discussion (FGD) with the local community at the Fatumnasi Village Office, there are several factors that prevent local people from not participating in the development of this tourist village, including:

- Lack of understanding and self-confidence in entrepreneurship. This means that people do not understand the right strategy in entrepreneurship in the tourism sector. Society is filled with a sense of pessimism rather than optimism about entrepreneurship.

- Weak local community human resources in the tourism sector. This means that people are aware of their limitations in knowledge regardless of their abilities and expertise in creating, processing, packaging and promoting local products.

- There is no place to promote packaged local products. There are complaints from the public regarding who and how to promote packaged products. This is an obstacle for local people to follow up on product packaging because previously packaged products are not sold out

- There is no synergy in strengthening cooperation between local communities, village governments (Bumdes), and tourism organizations (Pokdarwis) in developing their tourism potential, especially in packaging, promoting and selling their products.

\section{B. Efforts to Increase Local Community Participation}

There are also efforts that need to be made by the local community in supporting the Tourism Village program, namely:

- Involved in training and coaching in order to improve tourism human resources even with a limited educational status. In addition to increasing human resources in the tourism sector through the younger generation, not affected by the educational status of the community, they still have the opportunity to continue learning, equip themselves by following forms of socialization, training and coaching which are often held from various institutions and governments. The most important thing is that the community's intention does not recede but enthusiastically continues to learn and become an example for the younger generation. By 
being involved in this tourism activity, the community will continue to strive to innovate and verify their products.

- Collaboration between community groups in packaging local products. So far, it has not been clear that there is a good cooperative relationship between local communities. If there is good cooperation and people who have been active are enthusiastic to invite and teach people who have not actively participated, the success of tourism activities can be felt and enjoyed together. For this reason, cooperation between groups must continue to be fostered in order to create a peaceful and prosperous atmosphere.

- Creating harmonious cooperation between stakeholders, namely local communities, village government (Bumdes), tourism organizations (Pokdarwis), as well as non-governmental organizations (NGOs) and Sanggar Suara Perempuan (SSP) in promoting packaged local products. This really needs to be done considering that local communities really need government organizations, community organizations and other organizations that can support Fatumnasi tourism activities. Especially in promotional activities, every organization or institution can open up to help the success of the local community's business, for the sake of creating a community spirit in entrepreneurship.

\section{CONCLUSION}

Community participation is the key to success in supporting government programs, namely improving the economy towards a prosperous community in Fatumnasi Tourism Village, the results of the study show that local community participation is categorized as active even though it is still on a limited scale. Realized forms of local community participation include the formation of Pokdarwis, provision of facilities and infrastructure, packaging of local products, as well as involvement in training and development activities on tourism. There are factors that hinder the low participation of local communities, namely the weak local community human resources in the tourism sector, lack of understanding and selfconfidence in entrepreneurship, no place to promote local products, and the absence of synergy in strengthening cooperation between stakeholders. For this reason, community participation efforts that need to be done are involved in training and coaching in order to understand and improve tourism human resources, cooperation between community groups in packaging local products, and the need to create harmonious cooperation between stakeholders in promoting packaged local products.

\section{SUGGESTION}

Some of the recommended suggestions include:

- The government and related stakeholders need to provide encouragement and motivation to local communities to take part in the development of tourism designs.

- Increase local community participation in every tourism activity that can provide benefits to the local community itself.

- Increasing training and coaching to the community in turn so that other communities also participate in these activities.

- Involve local communities to actively participate in promoting local product packaging through exhibitions in district cities.

\section{REFERENCES}

[1] Law of republic Indonesia number 10 of 2009 concerning tourism.

[2] F. Abdillah, "Development of Tourism Destinations and Quality of Life for Local Communities," In Mimbar Journal, vol. 31, no. 2, pp. 339-350, 2015.

[3] B. Bagyono, Tourism \& Hospitality. Bandung: Alfabeta, 2014.

[4] B. Sunaryo, Concept of Tourism Destination Development Policy and Its Application in Indonesia. Yogyakarta: Gava Media, 2013.

[5] A. Theresia, A. Krisnha, P. Nugraha and T. Mardikanto, Community Based Development. Bandung: Alfabeta, 2014.

[6] L.G.L. Kusuma Dewi, "Efforts to Empower the Socio-Economic Community of Beraban Village in Sustainable Management of Tanah Lot," Tourism Journal Analysis, vol. 13, no. 1, pp. 23-44, 2013.

[7] L.J. Moleong, Qualitative Research Methodology. Bandung: Rosdakarya, 2010. 